\title{
The Antithesis of the Accusatory System. A proposal on the regulation of the Informal and Justified preventive prison towards a digital justice and according to the Human rights ${ }^{(*)}()^{* *}$
}

\author{
La Antítesis del Sistema Acusatorio. Una propuesta sobre la regulación \\ de la Prisión Preventiva Oficiosa y Justificada hacia una justicia digital y \\ acorde a los Derechos Humanos
}

\author{
Victor Manuel Solís Buitrón ${ }^{(* *)}$ \\ Universidad Nacional Autónoma de México (Mexico City, Mexico)
}

\begin{abstract}
Last August of this year, the Universidad Nacional Autónoma de México, through the Law School, by initiative of the College of Professors of Criminal Law, in response to the suspension of academic activities, as a result of the pandemic that afflicts the world arising from the SARS-Cov2 virus, taking advantage of digital platforms available to people at this time as a tool to use to communicate at a distance, organized the First International Virtual Congress of Criminal Law.

In this event, more than 130 academics from different Latin American Universities participated as speakers, who presented on topics of the criminal legal reality, both substantive and adjective, in the panels that were organized by themes that addressed different concepts in these specialties. The Congress was embellished by Magisterial Conferences issued by Masters Emeritus and Deans of the Faculty of Law of the UNAM and other law schools of invited countries.

The importance of the Congress surprised the Academic Forum, almost twenty thousand people registered and approximately two million of them accessed the event that was transmitted and broadcast on social networks through the Facebook platform "Live streaming". From the approaches that were most emphasized in the presentations, the concern of the present article is born. Specifically, it highlights concerns about exercise, it highlights the concern about the arbitrary exercise of criminal law due to its punitive nature and the importance of limiting the excess in its application, respecting in general the human rights of individuals and, in particular, those recognized for the parties in the procedural rules, this in equity with the Fundamental Principles of the Prosecution Systems in the accusatory model, already adopted in practically all democratic countries in Latin America. This highlights the need for a new definition of preventive prison, conceived now as a precautionary measure and its intimate relation with the principle of the "Presumption of Innocence", in whose application there must be absolute communion, a necessary condition in order to have a profound and definitive vision in the protection of Human rights.
\end{abstract}

Keywords: Criminal Law - Preventive prison - Presumption of innocence - Accusatory system - Informal preventive prison

$\left(^{*}\right) \quad$ Editor's Note: This article was received on September 15, 2020 and was approved for publication on November 12, 2020.

$\left({ }^{* *}\right)$ This paper has its antecedent in the author's presentation at Panel 15 on the topic: preventive prison and Cautionary Measures, held on August 7, 2020, at the First International Virtual Congress of Criminal Law, organized by the Faculty of Law of the UNAM.

$\left({ }^{* * *}\right)$ Head of the Oral Trials Department, School of Law, Universidad Nacional Autónoma de México. ORCID: https://orcid.org/0000-00025339-7393. Electronic mail: v.solis@sbam-abogados.com 
The Antithesis of the Accusatory System. A proposal on the regulation of the Informal and Justified preventive prison towards a digital justice and according to the Human rights

La Antítesis del Sistema Acusatorio. Una propuesta sobre la regulación de la Prisión Preventiva Oficiosa y Justificada hacia una justicia digital y acorde a los Derechos Humanos

Resumen: El pasado mes de agosto del presente año, la Universidad Nacional Autónoma de México, a través de la Facultad de Derecho, por iniciativa del Colegio de Profesores de Derecho Penal, atendiendo a la suspensión de actividades académicas como consecuencia de la pandemia que aqueja al mundo derivado del virus SARS-Cov2, aprovechando las plataformas digitales al alcance de las personas en estos momentos tan socorridas como instrumentos de uso para comunicarnos a distancia, organizó el Primer Congreso Virtual Internacional de Derecho Penal.

En este evento participaron más de 130 académicos de diferentes Universidades de Iberoamérica en calidad de ponentes, quienes expusieron sobre temas de la realidad jurídica penal, sustantiva y adjetiva, en las mesas que se organizaron por temáticas que abordaron diferentes conceptos de estas especialidades. El Congreso fue engalanado por Conferencias Magistrales emitidas por Maestros Eméritos y Decanos de la Facultad de Derecho de la UNAM y de otras escuelas de Derecho de países invitados. La trascendencia del Congreso sorprendió al Foro Académico, casi veinte mil personas inscritas y aproximadamente dos millones de ellas accedieron al evento que fue transmitido y difundido en redes sociales a través de la plataforma Facebook Live Streaming. De los planteamientos que más destacaron en las ponencias nace la inquietud del presente artículo. Específicamente resalta la preocupación al respecto del ejercicio arbitrario del derecho penal por su naturaleza punitiva y la importancia de limitar el exceso en su aplicación respetando en forma general los Derechos Humanos de las personas y de manera particular los reconocidos a las partes en las reglas procesales, esto en equidad con los Principios Fundamentales de los Sistemas de Enjuiciamiento en el modelo acusatorio, adoptados prácticamente ya en todos los países democráticos en América Latina.

Palabras clave: Derecho penal - Prisión preventiva - Presunción de inocencia - Sistema acusatorio - Prisión preventiva oficiosa

\section{Introduction}

The criminal justice systems in Latin America today are debating in the ideological universe of the values that make up their essence, which are the product of the idiosyncrasy and legal tradition of their regulations inherited by regimes that are essentially authoritarian or dictatorial, as opposed to the new paradigms that have been adopted as a result of international influence and between the need to protect the human rights recognized in their constitutions, as well as in the treaties integrated to their national legal orders in force, linked to the American System of Human Rights Conventions, in the face of the threat of crime that undeniably advances in an almost uncontrollable manner, challenging the organs of public security, the Attorney General's Office and the Administration of Justice, which are increasingly powerless to combat this social phenomenon, being in many cases surpassed in their structural functioning, to fall behind the claims and demands of citizens who, as victims, have been affected by this circumstantial reality.

To this criminal phenomenon, we must add the influence that the SARS-CoV2 virus, classified as a "pandemic" by the World Health Organization ${ }^{(1)}$, is having on our lives due to the effects it causes on individual's health. For this reason, it has been essential that the authorities of the countries order containment measures to prevent its spread and protect the health of their citizens, including social distancing and avoiding the concentration of people in public places, thus decreed the suspension of "non-essential" activities $^{(2)}$. This has led to a reduction in microeconomic indices that has led to the closure of businesses, a decrease in income in the economically active population, and even in thousands of cases to unemployment.

It has also had a considerable impact on the macroeconomy, as governments are less able to collect contributions, the closure of borders has slowed down imports and exports of products and even the supply of tourism, so public spending should prioritize health services mainly to address the pandemic and essential activities such as education, public safety and justice, among others.

Furthermore, everything points to the fact that the pandemic will last longer than

(1) See OPS (2020, March 31). La OMS caracteriza a COVID-19 como una pandemia. Pan American Health Organization.

(2) See Constitutional Presidency of the United Mexican States. (2020, March 31). Acuerdo DOF 31/03/2020. Por el que se establecen acciones extraordinarias para atender la emergencia sanitaria generada por el virus SARS-CoV2. Diario Oficial de la Federación. https://dof.gob.mx/nota detalle.php?codigo=5590914\&fecha=31/03/2020. It mentions the following:

"ARTICLE ONE - It is established as an extraordinary action, to attend the sanitary emergency generated by the SARS-CoV2 virus, that the public, social and private sectors must implement the following measures

I.- It is ordered the immediate suspension, from March 30 to April 30, 2020 to April 30, 2020, of the non-essential activities, in order to mitigate the dispersion and transmission of the SARS-CoV2 virus, in the community, to reduce the burden of disease, its complications and the death by COVID-19 in the population residing in the national territory; (...)" 
expected, perhaps until its final end when the virus will be controlled or extinguished, probably with its natural mutation or derived from the invention of the vaccine that we implore will be the solution to the tragedy we are living today. But we are still not completely sure, however we know that the world will no longer be the same and it is estimated that the problems among people will increase for the reasons mentioned, being latent the risk of breaking the social network.

In view of this, we recognize that the challenge today is complex, and lies in the need to adapt a solid and effective criminal justice system, which meets the needs and requirements of the parties, balanced in the exercise of the punitive power in equity, fully distinguishing the investigative powers of a public prosecutor's office, with respect to the functions of judging, those that must be deposited in a judicial branch that is independent and autonomous from the investigating body(3), attentive to the most elementary principles that justify its action in order to guarantee that the application of the penalties and the restriction of freedom are carried out in a fair manner and with respect for the fundamental rights of the actors on trial during all their procedural stages, from the beginning of the investigation to the execution of the sanctions.

Additionally, it is absolutely fundamental that governments implement measures and mechanisms towards digital or "online" justice. There is no doubt that the pandemic stripped the archaic from the way in which we have traditionally assumed the administration of justice in all its branches and specialties. It is inadmissible that despite the technological advances and the computer systems of this modernity, the courts had to suspend activities as a measure of containment to prevent the spread of the virus, falling asleep momentarily the sleep of the defendants in the cases in process and the differences between individuals during the time of compulsory confinement. Save for some exceptions, in the rest of the cases there was simply no competent court within the reach of the citizenry to deal with the claims of the defendant for transgressive conduct, this in total omission of the principle of "Judicial Guardianship".

The process of modernization of the systems to which we aspire in order to a new online justice, will also demand to adapt its formalities obeying the toral and absolute principles of the Accusatory System, specifically "Orality"; "Contradiction"; "Mediation"; "Continuity"; "Concentration"; "Equality of Parties"; "Legality"; "Presumption of Innocence" and "Due Process", since they constitute the backbone of an adversarial justice system according to the circumstances demanded by the present time.

To reach that goal, it is not enough to simply criticize by destroying the accusatory system by pointing out that it is dysfunctional under the argument of the "revolving door"(4), since this exhibits the State's inability to effectively exercise punitive power and its constitutional obligation to provide security to the citizens, which must be alien to the political parties or to the ideology of the governing group. The legal order is an element of the State that aims to resolve and settle the individual and social conflicts, which, in the case of the application of Criminal Law, given its punitive nature, in modern and progressive republics is instituted in a mechanism understood and applied as the ultimate reason for the political power destined to fulfill this task.

At the same time, it is not coherent to return to the traditional system, of mixed court (accusatory with inquisitive features), as historically it drags the shadow of obscurantist practices and violations of the fundamental rights, an application that today would be retrograde in function of the democratic evolution of the systems and the institutional development product of the constitutional republics that seek their full perfection, whose rules logically could not be harmonized with the parameters and requirements of an online justice.

(3) See Solís, V. (2018). Fiscalía General con Reforma Constitucional Sí o sí. Revista Barra Mexicana de Abogados, 106, 28-32. http:/l www.bma.org.mx/assets/la-barra-1062.pdf. He says: "This reform also modified the procedure for the appointment of the head of the Public Prosecutor's Office, making the appointment more demanding and rigorous; notwithstanding this, the constitutional amendment fell short of the expectation of guaranteeing the full and absolute autonomy that the Institution requires in its relationship with the Federal Chief Executive, which is evident from the moment that the President of the Republic retained the power to remove the public prosecutor for serious reasons established by law" (p. 28).

(4) See United Nations. (n.d.). Observaciones a México de la ONU-DH sobre la regulación de la Prisión Preventiva Oficiosa. http:// www5.diputados.gob.mx/index.php/esl/content/download/136357/681477/file/Anexo\%20ONU-DH\%20sobre\%20prisi\%C3\%B3n\%20 preventiva\%20oficiosa.pdf. In mentions that: "From this perspective, the non-application of preventative detention in criminal proceedings leads to the creation of a supposed "revolving door" in which "the criminals" who are arrested are freed, thus generating conditions of insecurity and impunity. However, this is not supported by empirical evidence; on the contrary, it has been demonstrated that in Mexico the supposed "revolving door" and the drivers of impunity are found in the deficient actions of the Prosecutor's Offices, especially in the early stages of criminal investigation" (italics added) (p. 9). 
The Antithesis of the Accusatory System. A proposal on the regulation of the Informal and Justified preventive prison towards a digital justice and according to the Human rights

La Antítesis del Sistema Acusatorio. Una propuesta sobre la regulación de la Prisión Preventiva Oficiosa y Justificada hacia una justicia digital y acorde a los Derechos Humanos

\section{Preventive Prison}

From our point of view, the most critical and complex aspect of the criminal prosecution systems lies in the preventive prison, which has been its eternal dilemma regardless of the inquisitorial, accusatory or mixed nature, it is very controversial due to its restrictive condition of freedom. Originally, the preventive prison was conceived as a mechanism of the punitive legal order to guarantee that the defendant does not escape the action of justice and therefore the process can fulfill its purpose.

It is regrettable that there are so many historically documented cases in which the accused was deprived of his liberty through the application of the preventive prison figure during his trial and after months or years inside a social confinement center, he was declared innocent in the criminal case against him, which surely must have caused damage to his economic, family, and social sphere, to his dignity and his psychological and emotional mood. This reality persisted, unfortunately justified by the law on the pretext that there was no alternative to prison as a mechanism to ensure compliance with the obligations of the accused in the process. Above all, we have always recognized that without a defendant there is no procedure and without a trial there is no just punishment, a condition equivalent to impunity.

The Inter-American Court of Human rights has recognized that the preventive prison is translated into an anticipated sentence ${ }^{(5)}$, by means of which the accused is condemned to a prison and submitted to the restriction of the freedom in confinement, without the existence of a sentence in which the full commission of the delicious fact and the reproach of his guilt is accredited, a priori to the relief of an exhausted trial in conformity with the essential formalities of the procedure, in which the accused is granted the opportunity to exercise his defense for the demonstration of his innocence.

This criticism is also aimed at the distortion of the preventive prison, which is essentially procedural in nature and should therefore only be applied during the investigation, prosecution, or trial stages, depending on the procedural rules of each system, otherwise, it becomes a punitive measure that loses the true sense of caution, a criterion also postulated by this human rights body(6).

Furthermore, the Inter-American Commission on Human Rights has recognized that the preventive prison violates the principles and guidelines that govern the imposition of this figure, this mechanism therefore becomes a form of arbitrary detention that violates the due process of the governed ${ }^{(7)}$.

Here there is an absolute parallelism between the concepts of preventive prison and due process. We cannot omit that the mentioned principle, is integrated by the set of procedural formalities that must invest the acts of authority as part of the requirement of the legality for its validity. Thus, considering that the preventive prison has been used as a mechanism for deprivation of liberty for procedural purposes, it is essential that the mandate that orders it, in addition to being based on the law, must be in accordance with due process.

But mainly the preventive prison undoubtedly attempts against the principle of innocence, conceived as a Human Right of protection and guardianship in favor of the people through which it is ensured that the citizen as an accused, is considered innocent during his prosecution, until his guilt is declared by a firm and irrevocable sentence and derived from a trial in which the due process is fulfilled.

Dr. Miguel Angel Aguilar Lopez (2015) says that:

The principle of innocence has as an angular basis to consider that by nature all men are innocent, not guilty, consequence of which is dabble to determine: any person subject to a criminal procedure or process is not considered responsible for the commission of the illicit until there is a signed sentence that declares him guilty. It is stated that it is attributed to him that it is a crime without, ex officio, any cause for its exclusion. The assertion of a crime requires an act or omission (simple or improper) that is malicious (direct or eventual) or culpable (foreseeable or unforeseeable) and that is exactly appropriate to the legal description as constituting a crime.

(5) See Inter-American Commission on Human Rights. (2006, February 1). Case of López Álvarez vs Honduras. Also, see the facts in the Technical Sheet: López Vs. Honduras in https://www.corteidh.or.cr/cf/jurisprudencia2/ficha_tecnica.cfm?nld_Ficha=322

(6) See Inter-American Commission on Human Rights. (2009, November 17). Case of Barreto Leiva vs Venezuela. Also, see the facts in the Technical Sheet: Barreto Leiva Vs. Venezuela in https://www.corteidh.or.cr/cf/jurisprudencia2/ficha_tecnica.cfm?nld_Ficha=357\&lang=e

(7) See Inter-American Commission on Human Rights. (2013, November 27). Case of J vs Perú. Also, see the facts in the Technical Sheet: J Vs. Perú in https://www.corteidh.or.cr/CF/jurisprudencia2/ficha_tecnica.cfm?nld_Ficha=370 
The accused from the moment a criminal conduct is attributed to him, he enjoys rights that tend to protect his person, dignity, freedom, honor and good name, and his quality as a subject in the investigation and not as the object of the investigation is guaranteed. It is important to mention that the objective of protection is the legal quality of the subject, with respect at all times to his right of presumption of innocence. That is, as long as his guilt is not proven, he is innocent regardless of the stage of the procedure in which he is, with unrestricted protection of his rights that are found in Section B of its article 20 Constitutional (Aguilar, 2015, p. 96)

In this way, the concept of presumption of innocence has evolved beyond a simple individual protection conferred to the accused to treat him as not guilty before the law and his process. This is due to the fact that its concept is much broader, so its interpretation and application must be extended in all its aspects and procedural rules.

In the opinion of Dr. Miguel Angel Aguilar Lopez, the principle of innocence as effective protection of the innocent, is composed of the following elements:

I. It is a human right of the accused, which can be described as polyhedral, of:

a. Conventional before its constitutional guardianship and in International Treaties.

b. Rule of treatment at all stages of the procedure (human dignity).

c. Even, their respect in the pre or procedural stage.

d. Test evaluation rule where:

- The judge is the one who values it.

- He must do it in a logical and freeway.

- Only the evidence that is given in court (with the exception of the anticipated evidence) is considered to be evidence.

- The presentation of the evidence is:

1. Before a judge who has not known about the trial previously.

2. Public Development, contradictory and oral.

3. Respect for the principle of contradiction.

II. The burden of proof to prove the guilt of the accused lies with the prosecution, as established by the criminal law (article 20, Paragraph A, Section V, of the Constitution). The public ministry, as the body responsible for investigating the crimes, is the only body empowered to assume the burden of proof on the accused.

III. In accordance with the principles of procedural equality, contradiction, the presumption of innocence, and effective State protection, the principle of adequate defense is enervated in favor of the accused (section b, fractions II to IX, of article 20 of the Constitution).
IV. Proof of charge must be lawful. Any evidence obtained through the violation of human rights (Federal Constitution, International Treaties, national and InterAmerican Court jurisprudence) is null and void.

V. The conviction must be based on the conviction of guilt of the accused. Beyond all reasonable doubt.

VI. The causes for the exclusion of the crime or the criminal responsibility are not accredited ex officio.
a. Atypicality
b. Causes for justification
c. Causes for incrimination or exclusion (Aguilar, 2015, pp. 75-76)

The concept proposed by the cited author defines presumption of innocence in a very complete way in its condition of general principle of law, which is why we decided to take it up again through the corresponding quotation, however, for the purposes of this work it should be understood only as an illustrative reference, since in the subject under discussion the approach is constrained by the influence and linkage of the presumption of innocence with preventive prison and its two different forms of application in the current system, i.e., informal and justified.

\section{Evolution of the Principle of Presumption of Innocence in Mexico}

The Political Constitution of the United Mexican States was promulgated in 1917, the product of an armed revolution of a social nature that gathered the main demands of the citizens, such as public, secular and free education, the rights of workers and the agrarian distribution, among others. In spite of containing a dogmatic part on the constitutional guarantees of individuals, it is paradoxical the lack of knowledge for almost a century of the principle of presumption of innocence, this is due to the authoritarian tradition of the political regime that governed in a hegemonic way for almost all the 20th century.

As for the criminal justice system, the figure of preventive prison was recognized 
The Antithesis of the Accusatory System. A proposal on the regulation of the Informal and Justified preventive prison towards a digital justice and according to the Human rights

La Antítesis del Sistema Acusatorio. Una propuesta sobre la regulación de la Prisión Preventiva Oficiosa y Justificada hacia una justicia digital y acorde a los Derechos Humanos

since the 1917 Constitution, and it was even argued that a presumption of guilt system was operating in Mexico, since it was legitimized by the Constitution, even though it had been since 1981, The Mexican State signed the American Convention on Human rights by adhering to this Treaty, an instrument that, as we know, recognizes the presumption of innocence as such, it is integrated into the current legal order in the National Statute. However, this was always a dead letter in Mexican Positive Law for two reasons:

Firstly, in accordance with article 133 of the Constitution, which provides for the normative hierarchy of the legal order in force, it establishes that the Constitution is the Supreme Law of every Union and, below it, all other legal systems, laws, regulations, decrees, and agreements at their different levels and in their areas of competence. Therefore, from the moment that the presumption of innocence as general principle of law was recognized in an international treaty, since the Conventional Instruments were legal statutes inferior to the fundamental rule, their application was contrary to the Supreme Mandate.

Secondly, at that time, the content of the concept of sovereignty as an element of the State, ignored any external power over the Fundamental Statute, given that sovereignty resides essentially in the people and is instituted through the latter expressed in the Constitution. Mexico's foreign policy is based on the principles of "Non-Intervention" and "Pacta Sunt Servanda". Thus, throughout history, the Mexican State has signed multiple bilateral and multilateral international treaties, whose obligations, in view of the second of the aforementioned principles, were interpreted as binding only between the States Parties and not with respect to the citizens, which is why the principle of presumption of innocence was also a dead letter in the current Legal Order.

This position was transformed with the passage of time, but at least three decades had to pass and two normative modifications had to occur to reach the constitutional recognition of the principle of presumption of innocence.

At the beginning of this century, the Supreme Court of Justice of the Nation, which was instituted by the Supreme Constitutional Court, through the criteria issued ${ }^{(8)}$, repositioned international treaties at a higher level than that recognized by the Supreme Statute, in equidistance with it. In this way, the conventions of International Law, being legal instruments signed by the Federal Executive and ratified by the Senate of the Republic, being attached to the Constitution, become Supreme Law of the whole Union above any regulation, overcoming the retrograde vision that ignored the obstruction of States parties to comply with the obligations assumed by their competent governing bodies, in international legal instruments. In this way, domestic laws that contravene the provisions of treaties and conventions have been modified in accordance with the constitutional and conventional supreme parameters.

It was after the Constitutional Reform in matters of criminal justice and public security published in 2008, when Mexico implemented the accusatory criminal system, that the obscurantism of that authoritarian tradition on the presumption of guilt was broken by finally including the principle of innocence in the Supreme Statute. However, its application was conditioned to two circumstances, the first was a "vacatio legis" for a period of eight years, a period granted for discussion, debate and training of the actors of the system on the new rules and for the drafting of the adjective legislation that governs the prosecution and the second to the changes in the paradigms in the field of human rights that occurred as a result of the reform of article 1 of the Constitution.

Thus, in June 2011, the constitutional reform of Human Rights came into force, transforming the traditional concept of constitutional guarantees into that of fundamental rights, understood as the prerogatives of men because of their human condition and which are conceived as intrinsic to people, recognized in the Constitution and in the International Treaties on this subject to which the Mexican State is a party, as well as the constitutional guarantees that are the mechanisms created by the fundamental norm to guarantee the unrestricted respect and care of the human rights and of its absolute application through the exercise of the diffuse conventional control that obliges all the authorities, independently of its jurisdiction, to respect and to comply in attention to the principles of "Progressivity" and "Pro Homine".

\section{Preventive Prison in the Traditional System}

In the traditional process of trial in Mexico, regulated by the Federal Code of Criminal

(8) See Suprema Corte de Justicia de la Nación. (2007). Tratados Internacionales. Son parte integrante de la ley suprema de la unión y se ubican jerárquicamente por encima de las leyes generales, federales y locales. Interpretación del artículo 133 constitucional. Semanario Judicial de la Federación. https://sjf.scjn.gob.mx/sjfsist/Paginas/DetalleGeneralV2.aspx?ID=172650\&Clase=DetalleTesisBL 
Procedures, come into force since 1931 and which was abrogated with the reform decree of law of 2016 that approved the National Code of Criminal Procedures currently in force, the application of preventive prison was subject to the qualification of the crimes recognized as serious. In the procedural legislation, the crimes were classified by their transcendence in serious and not serious crimes. The former was characterized by limiting the defendant to exercise the right to request provisional liberty on bail, by invoking fraction I of article 20 of the Constitution in force at the time, which, by qualifying as serious crimes, restricted the defendant's right to freedom through preventive prison.

In contrast, in the case of crimes known as non-serious crimes, the defendant could attend his trial at liberty, provided that he guaranteed two concepts: a) the pecuniary sanction comprised of the eventual reparation of damages in the event that the criminal figure so admitted, and the eventual fine decreed in the sentence in the event that this occurred, once the trial had been held and the defendant had been convicted; and b) the procedural obligations as economic measures imposed by the judge to make the defendant comply with the process itself.

Thus, the Federal Code of Criminal Procedures establishes, under the criterion of numerus clausus ${ }^{(9)}$, which crimes are considered serious and, by exclusion of those not contained in such provision were identified as non-serious crimes, and in such cases, it proceeds to provisional release on bail. This authoritarian concept, which arose from the nature of a mixed criminal justice system, prevailed until the new accusatory criminal justice system came into force.

Prior to the transition to the new adversarial procedure, the precursors of this system were severely critical of the institution of preventive prison and specifically of the catalog of crimes, pointing out that this conceptualization was contrary to the principles of the accusatory that they postulated essentially for two fundamental reasons: (i) because it limits the exercise of the judicial function to assess with full justice in which cases it is appropriate to restrict freedom on a provisional basis, since the identification of crimes as serious within a catalog causes the application of preventive prison by law as opposed to the discretionary function of the judicial organ solved in the evidentiary evaluation on the probable cause and; (ii) because such application of a restriction of freedom was not the result of a judicial decision prior to the discussion between the parties in a hearing that was conducted in accordance with the principles of the Accusatory System and in respect of the request by the prosecutor's office supported by the evidence on which it is based.

Thus, from the discussions surrounding the implementation process, it was postulated that the new criminal justice system would eradicate the catalog of crimes and the consequences of their arbitrary application, going beyond the identification of the crimes as serious and not serious, recognizing that in addition to preventive prison there are other ways to ensure that the defendant complies with his obligations before the law, the process and the offended. From here is born the concept of precautionary measures establishing fourteen different figures, some personal and others economic. In this way, the preventive prison was conferred such character, whose bases were imposed from the Constitution and regulated in the secondary legislation.

It was also established that the application of precautionary measures must always and at all times be in accordance with the principles of "Proportionality", "Exceptionality" and "Minimum Intervention". However, the principle of "Exceptionality" was incorrectly interpreted, in view of the United Nations Minimum Rules for Non-custodial Measures (Tokyo Rules) ${ }^{(10)}$, it was recommended that this figure should only apply to criminal conduct of major importance. Thus, in the drafting of the criminal reform of the accusatory model, these behaviors were referred to as high impact crimes, which were included in article 19 of the Constitution, which by exception would be considered crimes of Informal preventive prison, the effect of which, as we know, is to restrict the freedom of the accused from the stage of the initial formalized investigation and

(9) See article 194 of Federal Code of Criminal Procedures of the United Mexican States.

(10) See UN General Assembly. (1990, December 14). Resolution 45/110, Tokyo Rules. https://www.usmp.edu.pe/derecho/centro_ derecho_penitenciario/legislacion_internacional/Reglas\%20Minimas\%20de\%20las\%20Naciones\%20Unidas\%20Reglas\%20Tokio. pdf. The United Nations minimum rules on non-custodial measures (the Tokyo Rules) state: 6. Pre-trial detention as a last resort.

6.1 In Criminal Procedure, Preventive Prison shall be used only as a last resort, taking due account of the investigation of the alleged crime and the protection of society and the victim.

6.2 The alternative measures to Preventive Prison shall be applied as soon as possible. Preventive Prison shall not last longer than is necessary for the achievement of the objectives indicated in Rule 6.1 and shall be applied with humanity and respect for the dignity of the human being. (...) (p. 116). 
The Antithesis of the Accusatory System. A proposal on the regulation of the Informal and Justified preventive prison towards a digital justice and according to the Human rights

La Antítesis del Sistema Acusatorio. Una propuesta sobre la regulación de la Prisión Preventiva Oficiosa y Justificada hacia una justicia digital y acorde a los Derechos Humanos

until the oral trial which concludes with the sentence handed down by the Court of Proceedings.

The UN, through its Observations to Mexico on the regulation of informal preventive prison, has considered that this figure does not necessarily violate Fundamental Rights. UN says:

It is important to point out that the preventive prison per se is not a violation of human rights. However, as measures restricting the right to personal liberty, they must be based on the recognition of their exceptional nature and must be applied in accordance with the principles of legality, necessity and proportionality.

Preventive prison, the agency states, "is a precautionary measure (the most restrictive of the precautionary measures available to the State) that must always serve a legitimate procedural purpose: to ensure the appearance of the person charged with the criminal procedure and to control other procedural risks such as the obstruction of investigations and the endangerment of the integrity of victims and witnesses, as established in the first part of the second paragraph of article 19 of the Constitution (...) (ONU, n.d., p. 3).

In addition, the Constitutional Reform also included the figure of justified preventive prison. In this way the act of deprivation of liberty in addition to operating informally for the crimes expressly indicated in the fundamental norm, was also extended to any other as long as the concept of the need for caution is accredited, that is for any criminal figure foreseen and sanctioned by the criminal laws with a penalty of deprivation of liberty.

In this sense, the concept of the need for caution, which is universally known and recognized in accusatory legislation, is made up of: a) the risk of the accused escaping; b) the risk to the process, the evidence, and its protection; and c) the risk towards the offended and the victim, this means legally and materially that today the accused can be deprived of his or her liberty by any criminal figure regardless of whether it qualifies as informal or justified.

With regard to the treatment that the law confers on the figure of justified preventive prison, the following notes should be made: (i) This is the result of a request by the Prosecutor's Office as the accusatory body, a request that must be made in a public hearing and in the exercise of horizontal control between the parties. Let us not forget that this occurs during the Initial Hearing and at the specific time of the debate regarding the application of precautionary measures, specifically with regard to the preventive prison , which in Mexico, unlike other Latin American countries and the rules of the accusatory systems, occurs after the link to the process ${ }^{(11)}$ issued by the Control Judge, as a result of the establishment of evidence that presumes the participation of the accused in acts with the appearance of crimes, the prosecutor's office has previously stated at the same hearing that the charges are based on the same information as in the process link, the judge has a prior obligation to assess the facts and circumstances of the perpetrator as a result of the immediate surroundings, based on the presentation of the factual or legal proposals made by the accusatory body and assessed by the judicial authority in the Order of Attachment to the Process.

(ii) The Prosecutor is the accusatory organ, therefore it is necessary to take into account that the Latin American systems of prosecution today essentially accusatory, have their antecedents in mixed or inquisitorial court systems, in which the monopoly of the exercise of criminal action was deposited in the institution of the Public Ministry, granting it exclusive faculties of the prosecution of crimes and criminals ${ }^{(12)}$ and notwithstanding the principles of "Objectivity"; "Duty of Loyalty"; and "Due Diligence" conferred on the Public

(11) See article 19 of the Political Constitution of the United Mexican States. Regarding this, the dominant sector of the science of Criminal Law in Mexico, opposed its resistance to eliminate the period of the pre-trial stage integrated in the traditional procedure of mixed court recognized by the Political Constitution in force at the time and regulated by the procedural legislation, period of seventy-two hours initiated from the availability of the defendant before the Judge and concluded with the definition of his legal situation by means of a formal order of imprisonment, Subject to trial or release with the reservations of law as the case may be, with the possibility of extension for a period of 144 hours, at the request of the defense to offer and release evidence to distort the criminal act and the elements of the unjust criminal attributed to the accused. This period is partially equivalent to the period that currently elapses during the debate of the initial hearing or the formulation of the charges, in which the judge rules on whether or not the defendant is to be tried. This position was established in accordance with the authoritarian tradition applied in the previous system, which included prior investigations in the dark of the accused, denying him the right to know the accusation, the evidence against him and the opportunity to exercise his right to defense during the investigation stage in charge of the Public Ministry as the exclusive holder of the monopoly on the exercise of criminal action. 
Prosecutor's Office in the current Statute, there is a risk that the authoritarian tradition then deposited with the Public Prosecutor's Office will be imposed.

(iii) The evidence to demonstrate the need for caution is essentially subjective, first and foremost related to the accused, his risk to the process, to the evidence and to the victim, which results in order to the danger on these elements. Evidence of this is the risk assessment in the report issued by the corresponding area, which supposedly assesses with objective elements the need for caution. Therefore, we highlight the concept of dangerousness, a parameter of risk assessment, which leads us to believe that its incorrect use can lead to a regression in the spirit of criminal law, because it punishes individuals beyond the act committed as a result of their status as a perpetrator.

\section{Conclusions}

First, we criticize the traditional system's catalog of crimes, we do not currently call it that, but then what do we understand or how do we define the crimes sanctioned under the modality of informal preventive prison in terms of article 19 of the Political Constitution.

In particular, front my point of view, there is no difference between the denomination of serious crimes and the qualification of so-called high-impact crimes. In our opinion, the only difference between the two concepts is that in the former case, the crimes are established in the Procedural Code, as has been shown in this document, and in the latter, the said figures were drafted in the Constitution, which is more delicate since it is a federally applicable rule that is currently regulated by a National Procedural Code.
Second, in the new reform it was established that the Informal preventive prison would be of exceptional application, however since its first publication, its entry into force in the year 2016 and up to date, there has been an increase of more than 20 crimes punished under the modality of informal preventive prison, in addition to those that accumulate ${ }^{(13)}$, as part of the State's persecution policies to prevent and control crime, which are primarily authoritarian in nature.

It is even public knowledge that recently were presented in the Federal Congress, two initiatives that consider other figures in addition to those already recognized as crimes of informal preventive prison which implies the expansion of the list that cannot be denied the character of catalog, similar condition to that regulated in the previous system and that it is now intended to regulate in the National Code of Criminal Procedures, in this way to approve the reform in question, in the Mexican Criminal System we will have crimes of Informal preventive prison qualified as such in the Constitution as well as in the adjective law ${ }^{(14)}$.

Therefore, on July 30,2020 , an initiative was presented to the Federal Congress to reform article 167 of the National Code of Criminal Procedures, to include in this provision the application of informal preventive prison for the "crimes of abuse or sexual violence against minors, organized

(12) See article 21 repealed from the Political Constitution in the United Mexican States in force at the time. "(...) The imposition of penalties is proper and exclusive to the judicial authority. The investigation and prosecution of the crimes is the responsibility of the Public Ministry, which will be assisted by a police force that will be under its authority and immediate command (...)". Regarding this, despite the systematic change of paradigm that eliminates the monopoly power of the Public Prosecutor's Office to exercise criminal action, the Prosecutor's Office has inherited the authoritarian tradition of punitive prosecution, as I have commented to my students: "if it's a scorpion, it has a tail and poison, it's going to sting", analogically being an accusatory organ and as part of its nature it will generally request the application of justified preventive detention.

(13) See article 19 of the Political Constitution of the United Mexican States (original text of the 2008 Reform Initiative). "(...) The Public Prosecutor's Office may only ask the judge for preventive detention when other precautionary measures are not sufficient to guarantee the appearance of the accused in court, the development of the investigation, the protection of the victim, the witnesses or the community, as well as when the accused is being processed or has been previously sentenced for the commission of a fraudulent crime. The judge will order the preventive detention informally, in cases of organized crime, intentional homicide, rape, kidnapping, trafficking in persons, crimes committed with violent means such as firearms and explosives, as well as serious crimes determined by law against the security of the nation, the free development of the personality and health (...)" (italics added).

(14) See article 19 of the Political Constitution of the United Mexican States. "(...) The judge will order the preventive prison informally, in the cases of abuse or sexual violence against minors, organized crime, intentional homicide, femicide, rape, kidnapping, human trafficking, robbery of a house, use of social programs with electoral purposes, corruption in the case of crimes of illicit enrichment and abusive exercise of functions, robbery in the transportation of cargo in any of its modalities, crimes in the matter of hydrocarbons, The following crimes have been committed in the past: crimes against the security of the nation, the free development of the personality, and health, as well as serious crimes determined by law against the security of the nation, the free development of the personality, and health $(\ldots)$. 
The Antithesis of the Accusatory System. A proposal on the regulation of the Informal and Justified preventive prison towards a digital justice and according to the Human rights

La Antítesis del Sistema Acusatorio. Una propuesta sobre la regulación de la Prisión Preventiva Oficiosa y Justificada hacia una justicia digital y acorde a los Derechos Humanos

crime, intentional homicide, femicide, rape, kidnapping, human trafficking, burglary of a home, use of social programs for electoral purposes, corruption in the case of crimes of illicit enrichment and abusive exercise of functions, theft of cargo in any of its forms, crimes in the area of hydrocarbons, oil or petrochemicals, crimes in the area of forced disappearance of persons, and disappearances committed by individuals, crimes committed with violent means such as weapons and explosives, crimes in the area of firearms and explosives for the exclusive use of the Army, Navy, and Air Force, as well as serious crimes determined by law against the security of the nation, the free development of the personality, and health". (Secretaría de la Gobernación, 2020)

Third, in addition to informal preventive prison in the current criminal legislation, we have justified preventive prison, both of which operate as mechanisms for restricting freedom, the first of which is provided for by law and the second as a justified preventive measure, which, while it is true that its application stems from the judicial decision prior to the debate on the exercise of horizontal control, its determination is based on subjective elements whose application, in our opinion, imposes a restriction on the freedom of the accused based on the condition of the author and not on the attributed act. But mainly the application of this measure constitutes a dangerous weapon of the punitive power to restrict the freedom of the accused, beyond the Rule of Law, motivated by interests diverse to the principles and axiological values of criminal justice.

Therefore, it is time to rethink the systematic and functional regulation of the mechanisms of informal and justified preventive prison in order to make it harmonious with the human rights and the general principles of modern criminal law structured and recognized in the new paradigm of the accusatory system.

\section{Bibliographic references}

Aguilar, M. (2015). Presunción de Inocencia Derecho Humano en el Sistema Penal Acusatorio (1. ${ }^{\text {st }}$ ed.). Instituto de la Judicatura Federal. https://www.ijf.cjf.gob.mx/publicrecientes/2015/Presuncion\%20web.pdf

Secretaría de la Gobernación. (2020, March 3). Iniciativa que reforma el artículo 167 del Código Nacional de Procedimientos Penales, suscrita por el Diputado Ricardo Flores Suárez e integrantes del grupo parlamentario del PAN. http://sil.gobernacion.gob.mx/Archivos/ Documentos/2020/03/asun_4015908_20200310_1583272529.pdf

United Nations. (n.d.). Observaciones a México de la ONU-DH sobre la regulación de la Prisión Preventiva Oficiosa. http://www5. diputados.gob.mx/index.php/esl/content/download/136357/681477/file/ Anexo\%20ONU-DH\%20sobre\%20prisi\%C3\%B3n\%20preventiva\%20 oficiosa.pdf 